\title{
A Review of Obstacles of ICT Usage in Nigerian Tertiary Educational Institutions
}

\author{
Umar Musa (Corresponding Author) \\ Dept. of Educational Foundation, Faculty of Educational Studies \\ Universiti Putra Malaysia, 43330 UPM Sardang, Selangor, Darul Ehsan \\ E-mail: umarmusayakasai@gmail.com
}

Rosnaini Mahmud

Dept. of Educational Foundation, Faculty of Educational Studies

Universiti Putra Malaysia, 43330 UPM Sardang, Selangor, Darul Ehsan

E-mail: rosnaini@upm.edu.my

\author{
Habibah Ab. Jalil \\ Dept. of Educational Foundation, Faculty of Educational Studies \\ Universiti Putra Malaysia, 43330 UPM Sardang, Selangor, Darul Ehsan \\ E-mail: habibah.jalil@googlemail.com
}

Received: Sep. 24, 2018 Accepted: Oct. 16, 2018 Online published: Oct. 28, 2018

doi:10.5296/ijhrs.v8i4.13831ＵRL: https://doi.org/10.5296/ijhrs.v8i4.13831

\begin{abstract}
The use of Information and Communication Technology (ICT) in learning institutions is an order of the day in various parts of the world. This primarily has to do with its significance in teaching and learning on one hand, and its associated obstacles on the other. ICT been in used in Nigerian higher institutions for decades, steadily making progress, however, many obstacles were noted in the literatures. This study is conceptualized to review ICT usage in Nigeria and the associated obstacles amongst tertiary institutions in Nigeria. The study is asked to pinpoint these by extracting related literatures. The study identified obstacles such as inconsistent electricity supply, computer illiteracy, high cost of internet data and electronic services, fear of change, fear of redundancy, lack of adequate facilities and the issue of
\end{abstract}


internet and electronic security. It is suggested that provision of consistent electricity supply, training and ICT refresher courses and establishment of ICT centers to curtail cyber- crime etc. will go a long way in overcoming the barriers of effective integration and usage of ICT in the Nigerian tertiary institutions.

Keywords: ICT, obstacles, higher institutions, Nigeria

\section{Introduction}

ICT usage can be defined as the utilization of a diverse set of technological tools and resources that can be used to communicate, and to create, disseminate, store, and manage information (Saraf et al., 2016). According to Teo \& Beng Lee, (2010) ICT usage can be referred to as the utilization of the internet along with computer networks, World Wide Web, email and search engines used in the production and sharing of information. The advent of Information Communication Technology (ICT) into the Nigerian system of education has given rise to new modes of concepts in teaching and learning process, organizing courses, administration and management of the institutions, and even educational environment in schools and as well as the transformation of the roles played by the participants in the educational process (Umeagukwu Emmanuel \& Ngozi, 2014). Due to this improvement of ICT into the Nigerian tertiary education sector, there have been evident changes in the system that demands the academics, students and management staff, to follow the fashion by evolving and obtaining the knowledge of ICT so as to meet up with the dynamics of the $21 \mathrm{st}$ century. Meeting technological era necessitates the ability to become lifelong learners within a setting of cooperative and the ability to learn from the experts and move on with peers, social communities, and the world at large through the obtainable internet (Mahmud, Ndomi, \& Omodara, 2017). The development of any nation depends mainly on the quality of its education system, so goes the saying. While science and technology has revolutionized the whole world, the use of ICT in education has certainly influenced and enhanced teaching and learning processes. According to (Jaffer, Ng'ambi, \& Czerniewicz, 2007) ICT is expected to improve the quality and effectiveness and improve educational outcomes of teaching and learning. Traditionally, technological development has facilitated progressive human civilization, improved living environments, and increased human welfare (Anderson \& Dexter, 2005). In developing countries like Nigeria, ICT segment has been a pioneer and an influential facilitator in addressing the desire and interests of low-income communities (Okenwa, Francis, \& Abiahu, 2017). According to Kramer, Jenkins, \& Katz (2007) it was only in the last fifteen years that the consciousness and the appreciation for the ICT's role in the expansion of economic opportunity was appreciated.

Researchers in this era are more concerned about the significance of ICT in teaching and learning, and also experienced quick technological development and the living standard of the people were improved internationally (Sang, Valcke, van Braak, Tondeur, \& Zhu, 2011). To accurately understand the importance of ICT in teaching and learning, there is the need to actually understand the meaning of ICT. The term ICT refers to any planning which is capable of receiving, manipulating, storing, retrieving, transmitting of information or data (Onwuagboke, Singh, \& Fook, 2015). ICT permeates the business environment, it strengthens 
the success of modern corporations, and it provides governments with an efficient infrastructure. At the same time, ICT adds value to the processes of learning, and in the organization and management of learning institutions.

It is through the internet that, ICT becomes immensely important globally and enlighten the mind of people, develop critical thinking, accept new ideas and show creativity (Kisanga \& Ireson, 2014). In each and every society, the nation depends largely on the quality of education which is its bedrock, ICT is becoming important in our daily lives, and part and parcel of our education and brought remarkable changes in the technological era all over the world (Mahmud, Ndomi, \& Omodara, 2017).

Although, in the third world Countries, ICT has been accepted as the engine for growth and source of energy for social and economic empowerment of countries like Nigeria, these countries are empowering masses through IT as it provides effective short-cut to higher levels of equity in the emerging global digital networked information economy. In fact, ICT as an educational innovation in the school environment has a special and extraordinary place in the classroom (Tomei, 2005). In spite of these seeming advantages offered by ICT usage, yet, in Nigeria the development of ICT and its usage have been bedeviled by a number of obstacles which this paper is intended to explore and suggest possible solutions.

\section{Methodology}

As this study attempt to review the current status of ICT usage and the challenges confronting the utilization of information communication technology in Nigerian tertiary institution, and specifically to proper suggestions on how ICT usage can be improved. To accomplish these tasks, the researcher entirely relies on published secondary data from reputable sources including review of published articles from reputable international journals such as SAGE, JSTOR, Springer, IEEE, CEON, Hindawi, Nebraska, LearnTechlib and Elsevier amongst others.

Content Analysis has been used in planning the subject of this research and analyzing the whole data collected from the relevant secondary sources. The design in this particular research is used to demonstrate understanding and to study ICT usage in Nigerian tertiary institutions and how the identified problems could be overcome. This study has chosen content analysis method by selecting the relevant content of the various literatures related to this study; and the literature review enable the overall development of the study which ordinarily centered on theoretical and conceptual exploration.

\section{Discussion}

\subsection{The Recent Development of ICT Usage in Nigeria}

In this modern society, ICT is applied more and more widely, particularly for the purpose of teaching and learning (Rezaee, Jafari, \& Kazemzadeh, 2006). The whole world was revolutionized through science and technology and this progress depends solely on the quality of education (Jaffer, Ng'ambi, \& Czerniewicz, 2007). In Nigeria, ICT in education has certainly influenced and enhanced teaching and learning processes but have some associated 
challenges, these challenges serve as barriers or obstacles on the adoption of ICT as obtained in other famous higher institutions of the world. This is attributable to the influence of several factors which include but not limited to persistent computer illiteracy, cost of internet data, internet security, and electronic services, the lack of well-trained staff, fear of change, lack of facilities, and inconsistency in electricity supply and fear of being made redundant.

According to Ozioko \& Nwabueze (2010) the advancement in teaching and learning experiences by both lecturers and students in the Nigerian educational system was as a result of the introduction of a new era of ICT as against the traditional method of teaching.

The perfect new changed to student-centered methods was as a result of effective adoption and usage of ICTs in education which is at the heart of education reform in Nigeria (Johnson, Onwuegbuzie, \& Turner, 2007). Much progress has been achieved in the recent technological era of $21^{\text {st }}$ century since the inception of ICT in Nigerian system of education (Oladimeji and Folayan 2018). ICT is the foundation of every section of every economy in the world including Nigeria and it has been able to: reduce transaction costs and thereby improve productivity, channel knowledge and information of all kinds, substitute for others, more expensive means of communicating and transacting, such as physical travel, increase choice in the market place and provide access to otherwise unavailable goods and services and etc. (Kramer, Jenkins, \& Katz, 2007). According to Louis et al., (2010) unfortunately, most regions of Africa are yet to embrace ICTs appropriately. Teachers in most of Asia, Europe, and Australia have adapted in the utilization of ICTs in the classroom (López-Pérez, Pérez-López, Rodríguez-Ariza, \& Argente-Linares, 2013), unfortunately, in Nigeria and most of the African countries, teachers are still struggling with outdated tools (Dansarki, Ayub, \& Kadir, 2015). Although, in Nigeria and South Africa, the contributions of ICTs to national growth are highly valued than the rest of the developing countries of Africa (Awosejo, Ajala, \& Agunbiade, 2014). According to Olayiwola \& Alimi (2015) the lecturer's workloads can be reduced through the use of ICT in teaching and learning in colleges of education more specifically through its use of lecture preparation and instructional delivery, individualized and collaborative learning as well as learning evaluation.

The effectiveness of using ICT requires not only the availability of equipment but also their proper maintenance including other accessories such as scanners, multimedia projectors, computers, printers, and scanners (Khan, Hossain, Hasan, \& Clement, 2012). On the other hand, Scrimshaw, (2004) stress that the inaccessibility of ICT resources is not only due to the non-availability of the hardware and software or other ICT materials within an institution but a result of poor organization of resources, poor quality hardware, inappropriate software, or lack of personal access by lecturers.

\subsection{Obstacles of ICT Usage in Nigeria}

Proper integration of ICT usage in Nigeria is being affect by a number of factors amongst which include the followings;

\subsubsection{Inconsistent Electricity Supply}

In Nigeria, electricity supply is the biggest challenge to the growth and development of most 
industries and is a huge setback to the progress of Nigeria, as it is difficult to boast of one full day without electricity interruption.This is a big obstacle to ICT in Nigerian tertiary institutions, and indeed all industries require electricity in order to operate ICT and electronic gadgets (Azuh \& Modebelu, 2014). Another related study posits that proper infrastructure including electricity is fundamental and necessary for using the computers (Aduwa-Ogiegbaen \& Iyamu, 2005). The acquisition, deployment and management of information technology resources and services for teaching depend on electricity (Osakwe, 2012).

\subsubsection{Computer Illiteracy}

Many staff in the Nigerian tertiary institutions are not ICT computer literate and it is disappointing in this modern digital era (Idowu, Esere, \& Iruloh, (2017). As it is believed that practice makes perfect, most of the lecturers that studied computer application or undergoes computer training but without continuous practice is as good as nothing. According to Anene, Imam, \& Odumuh, (2014) illiteracy in this current age of ICT boom is really a great threat to any establishment, let alone of an educational institution whereas almost all human activities depend on ICT. It is interesting to note that as ICT is actually more important in tertiary institutions than most organizations. Within Nigerian tertiary institutions, specifically academic staff needs ICT for their numerous tasks which includes: students' assessments; exams and records, administration for managerial purposes, design and development of tertiary institutions website; and etc. (Beda et al., 2012). Computers cannot operate without electricity even if all the equipment required is present. Many lecturers in Nigerian tertiary institutions have never use computers in their lives as such they are terribly shy when they are confronted with this new technology and the terminology related with using them (Ajegbelen, 2016).

\subsubsection{High Cost of Internet Data and Electronic Services}

The high cost of internet data and electronic services, is basically the element of ICT usage and value and is one of the challenges of installing ICT in Nigerian tertiary institution (Tongia \& Subrahmanian, 2006). American government received huge amount of dollars from most of developing countries for the connection of few megabits per annum due to the fact that it has a strong hold and control of the ICT (Tongia \& Subrahmanian, 2006). This apparently affects the deployment and full utilization of ICT in these developing countries, of which Nigeria is inclusive. In Nigeria, the high cost of internet data and fast tariff set by internet providers, mostly international companies doing business in the country with the main interest of making profits is among the challenges of ICT deployment.

The high cost of getting, replacing, lack of technical support for maintenance of systems, operating, maintaining, installing, and ICT systems, use of unlicensed software, outdated hardware and software systems, are among obstacles of ICT usage as it relates to the higher institutions lecturers (Balasubramanian et al., 2009).

\subsubsection{Fear of Change}

Fear of change from old method of doing things to the new method is another challenging 
factor facing integration and usage of ICT in Nigeria tertiary institutions. Customarily, when modern ways is coming to replace the old method it appears challenging to any establishment be it tertiary institution or any form of organization. Consequently, maintaining the new method involves huge sum of money, time, planning, disruption, increase in personnel as the case may be and organizational change (Sherwani et al., 2004). According to Idowu \& Esere (2013) the tertiary institutions lecturers get the excuse that they are of older generation and have no time to learn the new generation's ways of doing things as such tend to shy away from modern technology.

\subsubsection{Fear of Being Made Redundant}

Usually, not only in Nigeria but throughout the world the introduction of technology is associated with reduction in need physical labour, leading to the laying off of so many workforce as such people's value in the society or organization will be reduced with the adoption of modern technologies (Anene, Imam, \& Odumuh, 2014). Again, Nigerian tertiary institutions are part of such illusive philosophical thinking, and which is the reason why most staff did not embrace it nor are they in support of any discussion about the ICT technologies (Oye, Salleh, \& Iahad, 2011). The introduction of ICT is seen as one of the threats to tertiary institutions academic staff, as most of them have been in the service for many years without its requisite knowledge (Azuh \& Modebelu, 2014).

The progress and development of any country depends largely on the ability to search for and learn new ideas of doing things better, thus creating more job opportunities and improved standard of living for the benefit of all citizens. According to Alturise \& Alojaiman, (2013) the challenge to ICT deployment can be dealt with by creating ICT awareness, which will help to ensure tertiary institutions staff that these technologies are operated by human beings, not meant to take the place of humans and when properly managed helps to lessen human burdens and make the work enjoyable.

\subsubsection{Lack of Adequate Facilities}

Another challenging factor militating against the deployment of ICT in Nigerian Tertiary institutions is Lack of facilities (Alturise \& Alojaiman, 2013). This is evident when compared to other tertiary institutions of the developed world, that Nigeria tertiary institutions lack basic office gadgets and technologies like computer, printers, faxing machines, photocopiers, binders, and projectors not even to talk of internet in most of the institutions particularly Colleges of Education. The dearth of these rudimentary facilities contribute to the challenges facing placement of ICT in Nigeria tertiary institutions, as no institutions can function effectively in this modern trend of ICT without these facilities. Apart from educational training, these office gadgets and technologies are so much vital and needed to equip students for future office and corporate activities after their studies. In a study conducted by Adeosun, (2010) showed that lack of ICT resources and poor infrastructure prevents full implementation of ICT in Nigerian tertiary institutions.

\subsubsection{Internet and Electronic Security}

Nigeria has bad reputation on the incidence of internet fraud and usage, which 
disappointingly discourage most responsible Nigerians from engaging in any electronic transaction or internet activities (Harijith, Ebenezer, \& Natarajan, 2014). This is the consequences of youth unemployment which forced most young people into cyber-crimes in order to survive. However, with the coming of present administration, the government is currently addressing these issues with the introduction of current Central Bank of Nigeria's $\mathrm{BVN}$ registration exercises in all banks. This is intended to tackle financial fraud and creation of new job opportunities to overcome youth unemployment. However, the disgrace of past experience is still in the blood stream of most responsible citizens and foreigners, of which the image of our tertiary institutions equally are not spared. This is a huge challenge to the deployment of ICT in Nigerian tertiary institutions more specifically colleges of education and has damaging reputation on Nigeria in the sight of other countries of the world. Consequently, people will just keep you at arm's length or being cautious in any business dealings with a Nigerian due to the wrong notion that Nigerians are fraudsters which is not true of all Nigerians.

According to Caperna (2010) some of those dubious elements engaging in fraudulent internet activities and electronic transactions is a challenge to ICT deployment in most Nigerian tertiary institutions particularly Colleges of Education. In order to guarantee security and instill confidence in people, the government is now making effort in collaboration with the Nigerian Universities Commission to ensure adequate security of universities electronic activities and internet dealings through a federal ICT center to be sited in each university in the Country. As stated by Robinson et al., (2010) this could be done by equipping each University ICT center with all it takes to battle cyber-crimes for adequate security and privacy of information.

\section{Conclusion}

The paper highlighted on the use of Information and Communication Technology (ICT) in learning institutions which has become the norms in various parts of the world. This primarily has to do with its significance in teaching and learning on one hand, and its associated obstacles on the other. ICT been in used in Nigerian higher institutions for decades, steadily making progress, however, many obstacles were noted in the literatures. This study reviewed ICT usage in Nigeria and the associated obstacles and hindrances amongst tertiary institutions in Nigeria. The study pinpointed these by extracting related literatures. The study identified obstacles such as inconsistent electricity supply, computer illiteracy, high cost of internet data and electronic services, fear of change, fear of redundancy, lack of adequate facilities and the issue of internet and electronic security. It is suggested that provision of consistent electricity supply, training and ICT refresher courses and establishment of ICT centers to curtail cyber- crime etc. will go a long way in overcoming the barriers of effective integration and usage of ICT in the Nigerian tertiary institutions.

\section{References}

Aduwa-Ogiegbaen, S. E., \& Iyamu, E. O. S. (2005). Using information and communication technology in secondary schools in Nigeria: Problems and prospects. Educational Technology \& Society, 8(1), 104-112. 
Ajegbelen, A. J. (2016). The use of ICT to enhance university education in Nigeria. International Journal of Education, Learning and Development, 4(5), 1-11.

Alturise, F., \& Alojaiman, B. (2013). Benefits and challenges of using ICT in Saudi Arabia universities: A literature review. Paper presented at the International conference on advanced in computing, Engineering and Learning Technologies.

Anderson, R. E., \& Dexter, S. (2005). School technology leadership: An empirical investigation of prevalence and effect. Educational Administration Quarterly, 41(1), 49-82. https://doi.org/10.1177/0013161X04269517

Anene, J., Imam, H., \& Odumuh, T. (2014). Problem and prospect of e-learning in Nigerianuniversities. International Journal of Technology and Inclusive Education (IJTIE), 3(2), 320-327. https://doi.org/10.20533/ijtie.2047.0533.2014.0041

Awosejo, P. P., Ajala, E., \& Agunbiade, O. (2014). Adoption of Accounting Information Systems in an Organization in South Africa. African Journal of Computing \& ICT, 7(1).

Azuh, O. J., \& Modebelu, M. N. (2014). Academic staff challenges to effective utilization of information and communication technology (ICT) in teaching/learning of agricultural education. International Letters of Social and Humanistic Sciences (ILSHS), 2, 88-96.

Balasubramanian, K., \& Clarke-Kah, W. (2009). ICTs for higher education. Background paper from the common wealth of learning UNESCO. Paper presented at the World Conference on Higher Education, Paris.

Balasubramanian, K., Clarke-Okah, W., Daniel, J., Ferreira, F., Kanwar, A., Kwan, A., ... West, P. (2009). ICTs for higher education: Commonwealth of Learning, Vancouver.

Beda, A., Brudanin, V., Egorov, V., Medvedev, D., Pogosov, V., Shirchenko, M., \& Starostin, A. (2012). The results of search for the neutrino magnetic moment in GEMMA experiment. Advances in High Energy Physics, 2012. https://doi.org/10.1155/2012/350150

Caperna, A. (2010). Integrating ICT into sustainable local policies Handbook of research on e-planning: ICTs for urban development and monitoring (pp. 340-364): IGI Global. https://doi.org/10.4018/978-1-61520-929-3.ch018

Culver, R., \& Yokomoto, C. (1999). Optimum academic performance and its relation to emotional intelligence. Paper presented at the Frontiers in Education Conference, 1999. FIE'99. 29th Annual. https://doi.org/10.1109/FIE.1999.840399

Dansarki, I., Ayub, A., \& Kadir, S. (2015). Hypothetical Prediction Of ICT Usage Behaviour Among Business Education Teachers In Nigerian Colleges Of Education. Australian Journal of Sustainable Business and Society, 1(2).

Ebersole, S. (2000). Uses and gratifications of the web among students. Journal of Computer-Mediated Communication, $\quad 6(1), \quad 0-0$. https://doi.org/10.1111/j.1083-6101.2000.tb00111.x 
Ehikhamenor, F. A. (2002). Socio-economic factors in the application of information and communication technologies in Nigerian print media. Journal of the Association for Information Science and Technology, 53(7), 602-611. https://doi.org/10.1002/asi.10044

Idowu, A., Esere, M., \& Iruloh, B. R. (2017). Computer Accessibility, Usage and Lecturers' Perception of Innovative Ictbased Assessment in a Nigerian University Sustainable Transformation in African Higher Education (pp. 215-226): Springer.

Jaffer, S., Ng'ambi, D., \& Czerniewicz, L. (2007). The role of ICTs in higher education in South Africa: One strategy for addressing teaching and learning challenges. International journal of Education and Development using ICT, 3(4).

Johnson, R. B., Onwuegbuzie, A. J., \& Turner, L. A. (2007). Toward a definition of mixed methods research. Journal of mixed methods research, 1(2), 112-133. https://doi.org/10.1177/1558689806298224

Khan, S. A., Bhatti, R., \& Ahmad Khan, A. (2011). Use of ICT by Students: A Survey of Faculty of Education at IUB.

Kisanga, D. H., \& Ireson, G. (2014). Challenges and strategies on adoption of e-learning in Tanzanian higher learning institutions: lessons to future adopters. Paper presented at the Proceedings of the International Conference on Information Communication Technologies in Education (ICICTE), 03-05 July 2014, Kos, Greece.

Kolodner, J. L. (2002). Facilitating the learning of design practices: Lessons learned from an inquiry into science education. Journal of Industrial Teacher Education, 39(3).

Kramer, W. J., Jenkins, B., \& Katz, R. S. (2007). The role of the information and communications technology sector in expanding economic opportunity. Cambridge, MA: Kennedy School of Government, Harvard University.

López-Pérez, M. V., Pérez-López, M. C., Rodríguez-Ariza, L., \& Argente-Linares, E. (2013). The influence of the use of technology on student outcomes in a blended learning context. Educational Technology Research and Development, 61(4), 625-638. https://doi.org/10.1007/s11423-013-9303-8

Louis, K. S., Leithwood, K., Wahlstrom, K. L., Anderson, S. E., Michlin, M., \& Mascall, B. (2010). Learning from leadership: Investigating the links to improved student learning. Center for Applied Research and Educational Improvement/University of Minnesota and Ontario Institute for Studies in Education/University of Toronto, 42, 50.

Mahmud, M., Ndomi, B., \& Omodara, A. (2017). STRATEGIES FOR IMPROVING THE PROVISION OF E-LEARNING FACILITIES FOR TEACHING AND LEARNING OF AGRICULTURAL EDUCATION IN COLLEGES OF EDUCATION IN NORTH EAST ZONE NIGERIA. ATBU Journal of Science, Technology and Education, 4(4), 166-173.

Mishra, P., \& Koehler, M. J. (2006). Technological pedagogical content knowledge: A framework for teacher knowledge. Teachers college record, 108(6), 1017. https://doi.org/10.1111/j.1467-9620.2006.00684.x 


\section{Macrothink}

International Journal of Human Resource Studies

ISSN 2162-3058

2018, Vol. 8, No. 4

Noor-Ul-Amin, S. (2013). An effective use of ICT for education and learning by drawing on worldwide knowledge, research, and experience: ICT as a change agent for education. Scholarly Journal of Education, 2(4), 38-45.

Okenwa, O. C., Francis, E., \& Abiahu, M. F. (2017). Assessment of Deferred Tax Recognition and Measurement under IFRS and Nigeria-SAS: An Empirical Examination.

Onwuagboke, B. B. C., Singh, T. K. R., \& Fook, F. S. (2015). Need for ICT Integration for Effective Instructional Delivery in Nigerian Colleges of Education. Journal of Education and Practice, 6(3), 51-56.

Oye, N., Salleh, M., \& Iahad, N. (2011). Challenges of e-learning in Nigerian university education based on the experience of developed countries. International Journal of Managing Information Technology, 3(2), 39-48. https://doi.org/10.5121/ijmit.2011.3204

Rezaee, M., Jafari, A., \& Kazemzadeh, E. (2006). Relationships between permeability, porosity and pore throat size in carbonate rocks using regression analysis and neural networks. $\begin{array}{lllll}\text { Journal of } \quad \text { Geophysics } & 370 .\end{array}$ https://doi.org/10.1088/1742-2132/3/4/008

Sang, G., Valcke, M., van Braak, J., Tondeur, J., \& Zhu, C. (2011). Predicting ICT integration into classroom teaching in Chinese primary schools: exploring the complex interplay of teacher-related variables. Journal of Computer Assisted Learning, 27(2), 160-172. https://doi.org/10.1111/j.1365-2729.2010.00383.x

Scrimshaw, P. (2004). Enabling teachers to make successful use of ICT.

Sherwani, J., Tongia, R., Rosenfeld, R., Ali, N., Memon, Y., Karim, M., \& Pappas, G. (2004). HealthLine: Towards speech-based access to health information by semi-literate users.

Teo, T., \& Beng, L. C. (2010). Explaining the intention to use technology among student teachers: An application of the Theory of Planned Behavior (TPB). Campus-Wide Information Systems, 27(2), 60-67. https://doi.org/10.1108/10650741011033035

Tomei, L. A. (2005). Taxonomy for the technology domain: IGI Global. https://doi.org/10.4018/978-1-59140-524-5

Tongia, R., \& Subrahmanian, E. (2006). Information and Communications Technology for Development (ICT4D)-A design challenge? Paper presented at the Information and Communication Technologies and Development, 2006. ICTD'06. International Conference on.

Umeagukwu, E. O., \& Ngozi, E. B. (2014). An Analysis of ICT impact on the Curricular of Major Nigerian Universities in the Last Ten Years 2003-2013. International journal of science and Technology, 3(1). 


\section{Copyright Disclaimer}

Copyright for this article is retained by the author(s), with first publication rights granted to the journal.

This is an open-access article distributed under the terms and conditions of the Creative Commons Attribution license (http://creativecommons.org/licenses/by/4.0/). 